九州大学学術情報リポジトリ

Kyushu University Institutional Repository

Factors Influencing the Willingness to Join CBO Biogas Self-Help Group in Mulyorejo Urban village and Karangnongko Village in Malang, Indonesia

Prayitno, Gunawan

Urban and Regional Planning Department, Brawijaya University

Annisa Nurul Hakim

Urban and Regional Planning Department, Brawijaya University

Meidiana, Christia

Urban and Regional Planning Department, Brawijaya University

https://doi.org/10.5109/4150466

出版情報 : Evergreen. 7 (4)，pp.468-480，2020-12. 九州大学グリーンテクノロジー研究教育センター バージョン：

権利関係 : 


\title{
Factors Influencing the Willingness to Join CBO Biogas Self- Help Group in Mulyorejo Urban village and Karangnongko Village in Malang, Indonesia
}

\author{
Gunawan Prayitno ${ }^{1, *}$, Annisa Nurul Hakim ${ }^{1}$, Christia Meidiana ${ }^{1}$ \\ ${ }^{1}$ Urban and Regional Planning Department, Brawijaya University, Indonesia \\ *E-mail: gunawan_p@ub.ac.id
}

(Received 19 August 2020; Revised 15 October 2020; accepted 19 October 2020).

\begin{abstract}
A non-governmental organization (Community Base Organization, CBO) plays a significant role in managing resources or regional community-based services. This study determines the factors influencing the respondents' willingness to join CBO methane gas (biogas) for green energy in Mulyorejo Urban village and Karangnongko villages in Malang City and Malang Regency, respectively. Variables were determined using a logistic regression model. The chances of respondents' willingness to join were assessed through a probability analysis. This created a scenario with the highest likelihood of willingness. The results showed that the chances of the respondents entering Mulyorejo urban village could reach $99 \%$ when factors such as employment, methane gas benefits, finance, education, as well as invitations from family, friends, neighbors, and government were involved. Also, the chances of respondents joining CBO methane gas in Karangnongko Village reached $99 \%$ when factors such as methane gas benefits, finance, social participation, as well as invitations from family, friends, neighbors, and government were involved.
\end{abstract}

Keywords: methane gas (biogas), green energy, management, self-help group, willingness to join

\section{Introduction}

Supit Urang and Paras Landfills in Mulyorejo urban village and Karangnongko villages, respectively, have methane gas (biogas) treatment plants as green energy used by local residents. In 2019, the number of methane gas users in Mulyorejo Urban village reached 130 households. This was only $2.8 \%$ of the total households in that village. In Karangnongko, only 166 used methane gas, which is only $6 \%$ of total households in that village. Various studies show that the number of users in both regions has decreased, particularly in the Mulyorejo urban village, which experienced a significant reduction from 2012 to $2019^{1)}$. This is unfortunate because the methane gas (biogas) program's sustainability is threatened with the decline in the number of users. Biogas may come from animal waste, olive pomace ${ }^{2)}$, or other materials. This study discusses the biogas from animal waste. The government is introducing its methane gas (biogas) delivery scheme to minimize people's costs ${ }^{3)}$. The program was submitted to the local community to be managed independently by a non-governmental group (CBO). The $\mathrm{CBO}$ responsible for managing the methane gas network in the Mulyorejo Village is Bina Mandiri CBO, set up in 2012. Similarly, the methane gas in Karangnongko Village is managed by Cempoko Mulyo $\mathrm{CBO}$, established in 2011. Both programs are implemented to reduce air pollution due to the release of methane gas (biogas) from the landfills at Supit Urang and Paras sites.

The Community Base Organization (CBO) is a nongovernmental group of people with the same vision, interests, and needs voluntarily uniting to achieve a common goal ${ }^{1)}$. CBO is characterized by self-help and social assistance ${ }^{4,5)}$, built and dissolved through a community agreement, as well as non-partisan and autonomous among other institutions. The study shows that the self-help group (SHG) is an informal grouping of individuals voluntarily participating for economic purposes. It is a tool to assist village development and poverty alleviation efforts ${ }^{6-8)}$.

This study determines the factors influencing the willingness of non-methane gas users to join the CBO. The invitation was made to gauge the residents' enthusiasm towards the government's methane gas development plan. Additionally, this invitation seeks to strengthen social capital. The opinion states that the size of social networks is influenced by the number of participants in the group ${ }^{9,10)}$. Community social capital needs strengthening to achieve more efficient infrastructure management programs ${ }^{6,11)}$. Therefore, social capital is needed in the community ${ }^{12)}$, organization ${ }^{13)}$, and the program implementation ${ }^{14)}$ to ensure its sustainability. Social capital is a media of power-sharing 
within groups. It facilitates an exploration of community resources to effectively achieve shared objectives ${ }^{15-17)}$.

This research is a comparative study ${ }^{18)}$ that determines the differences and similarities in the factors influencing the willingness of non-methane gas users to join the CBO. Comparative research finds cause and effect by analyzing the occurrence factors of phenomena. This is accomplished by comparing similarities and differences between the objects under study ${ }^{19}$ ). The researcher limits the discussion to comparative study, focusing on the

\section{Methods}

\subsection{Logistic Regression}

Logistic regression is the analytical method used to calculate the chances of people joining $\mathrm{CBO}$ in methane gas. Also, the method is used to determine the factors influencing people's willingness to join the group. Logistic regression analysis is used to model the relationship between one or more independent and dependent variables. In this case, the dependent variable is binary or dichotomous ${ }^{22-24)}$. Such variables have only two possible values, the "yes" and "no" or "high" and"low," often referred to as 1 and $0{ }^{25}$. The data used for independent variables may be nominal, ordinal, interval, or ratio ${ }^{26)}$. Logistic regression is non-linear. It is used to explain the non-linear relationship between $\mathrm{X}$ and $\mathrm{Y}$, the $\mathrm{Y}$ distribution abnormalities, and the diversity of non-constant reactions that cannot be explained by ordinary linear regression models ${ }^{27}$.

Logistic regression analysis does not require many assumptions, such as data normality. It does not assume linearity of the relationship between independent and dependent variables, requires no multivariate data distribution, and does not assume homoscedasticity ${ }^{28)}$. Logistic regression is used to forecast the dependent variable by one or more variables. Moreover, it is used to assess the variance percentage in the dependent variable explained by the independent variable and to rate significance. The selection of logistic regression in the study was adjusted to determine the factors and questionnaire questions. The willingness to join was seen in the form of a "willing and not willing" (dichotomous) question. Factors influencing the willingness to join are seen from the community's opinion. This shows whether or not these factors affect the community. The formula for logistic regression is as follows (Eq. 1):

$\operatorname{Ln}\left(\frac{P}{1-P}\right)=\beta_{0}+\beta_{1} X_{1}+\beta_{2} X_{2}+\ldots \ldots . \beta_{n} X_{n}$

where:

Ln = Natural logarithm

$\mathrm{P} \quad=$ Probability

B0 = Beta coefficient constant

$\beta 1, \beta 2 \ldots . \beta \mathrm{n}=$ Odd ratio on each independent variables similarities and differences in factors influencing the community's participation in the study area.

Previous studies showed that individual behavior directly or indirectly affects the environment, regardless of how it is influenced by various groups ${ }^{7,20)}$ and the position of social capital ${ }^{12,21)}$. This study explores how individual activity in two separate groups is primed for membership in CBO and the effect of social capital on the program's sustainability.

The dependent variable (Y) in this study is the willingness to join. The independent variables $(\mathrm{X})$ consist of methane gas network (X1), ages (X2), occupation (X3), income (X4), education (X5), methane gas benefit (X6), methane gas effect (X7), policy knowledge (X8), awareness (X9), financial (X10), social status (X11), social participation (X12), invited by family/friends/neighbors (X13), and invited by the government (X14).

The probability analysis is performed after modeling the factors affecting the willingness to join the CBO methane gas. This analysis is useful in producing modeling scenarios used to test the models made. The following is a formula to calculate an event's probability (Eq. 2).

$$
P i=\frac{e^{(\beta 0+\beta 1 X 1+\cdots \cdot \beta n X n)}}{1+e^{(\beta 0+\beta 1 X 1+\cdots \beta n X n)}} \frac{e^{(\beta 0+\beta 1 X 1+\cdots, \beta n X n)}}{1+e^{(\beta 0+\beta 1 X 1+\cdots \beta n X n)}}
$$

where:

$\mathrm{Pi} \quad=$ Probability of factors affecting the willingness to join the methane gas $\mathrm{CBO}$

e $\quad=$ Exponents

$\beta_{0} \quad=$ Beta coefficient constant

$\beta_{1}, \beta_{2} \ldots \beta_{\mathrm{n}}=$ Odd ratio on each independent variables

The factors affecting the willingness to join are modeled by exponentially comparing the value of variables in the model. Hence, the scenario-setting stage becomes an alternative to finding out the probability that the community joins the CBO.

\subsection{Population and Sampling}

The study population is the number of households not included in the CBOs member. Also, they are referred to as non-methane gas respondents in the two study areas. The total population of methane gas non-users of the Mulyorejo Urban Village and Karangnongko Village is 71.677 households ${ }^{29}$ ). Therefore, the number becomes the basis for the proportional population sampling in each region.

The number of non-methane gas households in the Mulyorejo Urban village and Karangnongko villages is 
4.622 and 2.545 , respectively ${ }^{29)}$. The sample for factors affecting the willingness to join was determined using a simple random sampling technique. This technique is used to select samples from homogeneous populations of equal opportunities ${ }^{30}$ ). The target respondents were nonmethane gas users in Mulyorejo urban village and Karangnongko villages. The sampling was calculated using the Slovin formula with an error tolerance limit of 5\%, as follows (Eq. 3):

$$
n=\frac{N}{N \cdot e^{2}+1}
$$

Where:

$\mathrm{n}$ : sample numbers

$\mathrm{N}$ : populations

e: standard error $(0,05)$

From the formula, there are 379 respondents to the research sample. The Slovin formula results are then recalculated according to the proportion of the number of respondents for the collected samples to represent the populations in both villages. The proportioned calculation results show that the number of samples for Mulyorejo Urban village and Karangnongko villages is 244 and 134, respectively.

\section{Result and discussion}

\subsection{Research Sites}

The study was conducted in Mulyorejo urban village and Karangnongko villages, which are in Malang City and Malang Regency, respectively. The study area was determined based on the presence of two user communities and a group of CBO methane gas managers. Currently, there is only one methane gas community in Malang, the Mulyorejo urban village. Malang Regency has two methane gas communities, the Karangnongko and Talangangung villages. Nevertheless, the community and management group of Talangagung village are no longer active. This leaves Karangnongko as the only methane gas community in Malang Regency.

Mulyorejo Urban village is located in west of Malang City, directly adjacent to Malang Regency. Meanwhile Karangnongko Village is in the east of Malang Regency. Malang City and Malang Regency are geographically neighbor to each other, both region are part of the East Java Province in Indonesia (Fig. 1 \& Fig. 2).

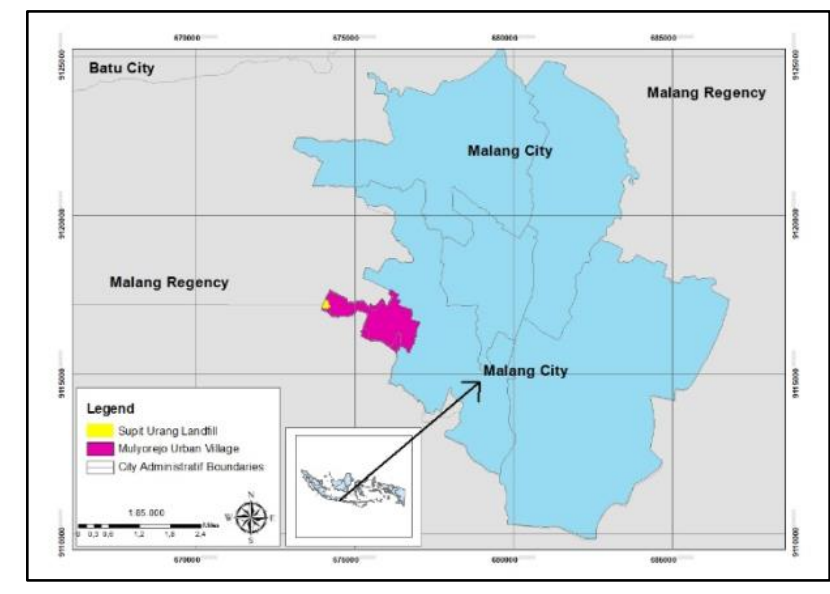

Figure 1. Research Site of Mulyorejo Urban Village

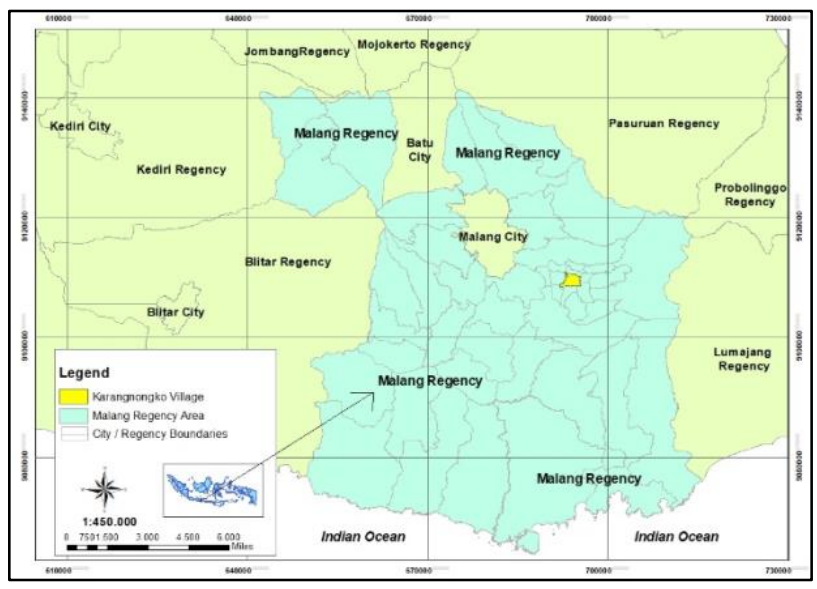

Figure 2. Research Site of Karangnongko Village

\subsection{Self-help Group in Mulyorejo urban village and Karangnongko villages}

Self-help groups or CBOs are NGOs. They are groups of actively interested people because of shared goals and desires ${ }^{1)}$. In this study, CBOs are the self-help groups contributing to the management of methane gas distribution from landfills to settlements. CBO Bina Mandiri is responsible for managing methane gas from the Supit Urang Landfill in Mulyorejo Urban Village. The Supit Urang is the only landfill in Malang City, covering 32 hectares. CBO Bina Mandiri was established in 2012 at the Malang City Department of Sanitation to minimize methane gas emissions from the waste heap. Its members registered 130 families in 2019. The company's organizational structure comprises the president, secretary, treasurer, and two mechanics responsible for every-day pipeline operation.

CBO Cempoko Mulyo operates the methane gas network in Karangnongko Village. The Malang District Sanitation Office was established in 2011 in CBO Cempoko Mulyo. Compared to the Mulyorejo Village Methane Gas Project, which is part of the local sanitation department, a settlement officer at Paras initiated the 
methane gas utilization system in Karangnongko Village. The concept was made after the Talangagung Final Disposal Site succeeded in methane gas management and usage. Therefore, the Paras Final Disposal Officer is applying the same methane gas processing technology as in the Talangagung Final Disposal Site. In contrast, Talangagung Landfill's methane gas collection technology uses an invention created with petung bamboo by the Paras landfill officer. The results were satisfactory for the two weeks of the experiment, with the gas flame relatively stable and large. Also, the landfill suggested a plan on the methane gas pipeline for the Paras site group to the Malang Regency Environmental Office. The number of CBO Cempoko Mulyo participants was relatively constant from the initial preparation, from 180 households to 166 in $2019^{1)}$. Group leaders, secretaries, treasurers, and withdrawals of contributions consist of 3 persons.

\subsection{Factors that influence the willingness to join CBOs}

Factors influencing the willingness to participate are taken from two theories. The first theory is on the factors affecting environmental behavior ${ }^{20,31)}$, while the second is on those influencing individual attitudes towards group motivation ${ }^{7}$. Theories arguing that factors influencing environmental behavior are assessed from several aspects, including environmental values, situational variables, and psychological factors ${ }^{20)}$. Such factors are classified into several sub-variables, including:

1. Environment values

Individual activity directly or indirectly influences the environment. Therefore, the importance of the environment is connected to environmental knowledge and activity, ${ }^{20)}$. The concept provides an interpretation of whether or not individuals are environmentally friendly. Therefore, in this study, environmental value is associated with a willingness to join $\mathrm{CBO}$. This is because by becoming a $\mathrm{CBO}$ member, the community has a role to play in reducing global warming ${ }^{32)}$ due to methane through gas consumption.

2. Situational Variable

a. Behavioral context

Behavioral context refers to the community's efforts or willingness to perform activities towards environmental concern. Previous studies revealed that activities that have shown concern are characterized by individual awareness of household waste recycling, ${ }^{20)}$. The behavioral framework in this study is associated with the availability of methane gas networks. This is because the presence of methane gas networks around the respondent's home affects the readiness to join CBOs.

b. Socio-demographics

The socio-demographics identified were age, occupation, education, and income. Previous research, ${ }^{20)}$ suggested that socially demographic characteristics influence individual behavior in environmental care and management.

1) Ages

In this analysis, the ages were divided into productive and non-productive. The productive and non-productive age limits were determined based on the Indonesian BPS standard. It states that the productive age range is 15-64 years, while the nonproductive age group comprises people under 15 and over 64.

2) Occupation

Occupation is classified into non-work, nonpermanent work, and permanent work. The reason for separating the working groups applies to Ministerial Decree No.100 of 2004 33).

3) Educational variables

Educational variables are categorized as 9 years of basic education and 9 years of education. According to Law No.20 of 2003 on the National Education System 34), national education in Indonesia currently provides that the compulsory basic education program is 9 years. This includes six years in primary school and three years in junior high school. Starting from high school, diploma, to college.

4) Respondent's income

This study's respondents' income is categorized below the Regional Minimum Wage (RMW) and above the RMW. Administratively, Mulyorejo Village is part of the Malang City area, while the Karangnongko Village is part of the Malang Regency area. According to BPS data, the 2018 RMW of Malang City (year of research was Rp.2.272.167, while the Malang Regency had Rp2.368.510.

c. Knowledge

Environmental knowledge plays a significant role in shaping behavior ${ }^{20)}$. In this study, knowledge was assessed on three issues. The first issue was the benefits of methane gas (symbol of clean environment ${ }^{35}$ ) or energy). The second issue was the impact of methane gas. The third issue was the policy knowledge. This focuses on public knowledge of government policies on methane gas programs. Also, it concerns the policies being implemented in Mulyorejo Urban and Karangnongko villages.

3. Psychological factors

Psychological factors depend on the fact that individual perceptions determine the environmental actions of each person. In this study, psychological considerations concentrate on perception issues 
relevant to public awareness of the benefits of methane gas and entering CBOs. Individuals with an awareness of the benefits of methane gas consider joining a $\mathrm{CBO}$ to positively affect environmental and economic aspects. They join the $\mathrm{CBO}$ voluntarily.

The second theory notes that factors influencing individual attitudes towards group motivation are affected by the intent and motivation to participate ${ }^{7)}$. The membership object is divided into various sub-variables, including financial, social, and social status improvement. The impetus for membership is motivated by the invitation of relatives, friends, neighbors, and the government.

Table 1. Factors of willingness to join in Mulyorejo urban village and Karangnongko villages

\begin{tabular}{|c|c|c|c|c|}
\hline \multirow{2}{*}{ Variables } & \multicolumn{2}{|c|}{ Respondent in Mulyorejo Urban Village } & \multicolumn{2}{|c|}{ Respondent in Karangnongko Village } \\
\hline & Statement & Percentage & Statement & Percentage \\
\hline \multirow{2}{*}{ Willingness to join } & Willing to join & $83.2 \%$ & Willing to join & $82.8 \%$ \\
\hline & Not willing to join & $16.8 \%$ & Not willing to join & $17.2 \%$ \\
\hline \multirow{2}{*}{ Methane gas network } & Available & $18.4 \%$ & Available & $28.4 \%$ \\
\hline & Not available & $81.6 \%$ & Not available & $71.6 \%$ \\
\hline \multirow{2}{*}{ Ages } & Productive age & $92.6 \%$ & Productive age & $91.0 \%$ \\
\hline & Non Productive age & $7.4 \%$ & Non Productive age & $9.0 \%$ \\
\hline \multirow{3}{*}{ Occupation } & Not Work & $35.7 \%$ & Not Work & $26.9 \%$ \\
\hline & Non-Permanent Work & $57.0 \%$ & Non-Permanent Work & $61.9 \%$ \\
\hline & Permanent Work & $7.4 \%$ & Permanent Work & $11.2 \%$ \\
\hline \multirow{2}{*}{ Income } & Above RMW & $18.9 \%$ & Above RMW & $18.9 \%$ \\
\hline & Under RMW & $81.1 \%$ & Under RMW & $67.9 \%$ \\
\hline \multirow[t]{2}{*}{ Education } & $\begin{array}{l}\text { Above } 9 \text { years of basic } \\
\text { education program }\end{array}$ & $38.1 \%$ & $\begin{array}{c}\text { Under } 9 \text { years of } \\
\text { basic education } \\
\text { program }\end{array}$ & $41.0 \%$ \\
\hline & $\begin{array}{c}\text { Under } 9 \text { years of basic } \\
\text { education program }\end{array}$ & $61.8 \%$ & $\begin{array}{c}\text { Under } 9 \text { years of basic } \\
\text { education program }\end{array}$ & $58.9 \%$ \\
\hline \multirow{2}{*}{ Methane gas benefit } & Know & $70.5 \%$ & Know & $59.7 \%$ \\
\hline & Not know & $29.5 \%$ & Not know & $40.3 \%$ \\
\hline \multirow{2}{*}{ Methane Gas Effect } & Know & $27.5 \%$ & Know & $29.8 \%$ \\
\hline & Not know & $72.5 \%$ & Not know & $70.1 \%$ \\
\hline \multirow{2}{*}{ Policy Knowledge } & Know & $9.4 \%$ & Know & $6.7 \%$ \\
\hline & Not know & $90.5 \%$ & Not know & $93.2 \%$ \\
\hline \multirow{2}{*}{ Awareness } & Aware & $61.1 \%$ & Aware & $31.3 \%$ \\
\hline & Unaware & $38.9 \%$ & Unaware & $68.7 \%$ \\
\hline \multirow{2}{*}{ Financial } & Agree & $68.8 \%$ & Agree & $73.1 \%$ \\
\hline & Dis agree & $31.2 \%$ & Dis agree & $26.9 \%$ \\
\hline \multirow{2}{*}{ Social Status } & Agree & $63.5 \%$ & Agree & $36.5 \%$ \\
\hline & Dis agree & $40.3 \%$ & Dis agree & $59.7 \%$ \\
\hline \multirow{2}{*}{ Social Participation } & Agree & $39.3 \%$ & Agree & $55.2 \%$ \\
\hline & Dis agree & $60.7 \%$ & Dis agree & $44.8 \%$ \\
\hline \multirow{2}{*}{$\begin{array}{c}\text { Invited by family/friends/ } \\
\text { neighbors }\end{array}$} & Agree & $75.0 \%$ & Agree & $81.3 \%$ \\
\hline & Dis agree & $25.0 \%$ & Dis agree & $18.7 \%$ \\
\hline \multirow{2}{*}{ Invited by Government } & Agree & $85.2 \%$ & Agree & $92.5 \%$ \\
\hline & Dis agree & $14.8 \%$ & Dis agree & $7.5 \%$ \\
\hline
\end{tabular}

The field survey results in Table 1 show a high level of willingness to join the respondents in both regions. The willingness to join respondents in Mulyorejo Urban village and Karangnongko villages was $83.2 \%$ and $82.8 \%$, respectively. Although no methane gas network is developed around the respondent's building, the willingness to enter is high. This is indicated by the small percentage of respondents saying that methane gas was built outside their homes. In Mulyorejo Village, $18.4 \%$ of respondents reported a methane gas network around their home, while $28.4 \%$ reported the same in Karangnongko Village. The strong willingness to join in Mulyorejo village is due to the proposal to install a large-scale methane gas network. The system is set to begin in 2020, with methane gas service network size able to serve all houses in Mulyorejo Urban Village. The local government is still researching the decision to install a methane gas network in Karangnongko Village. 
The social demographic factors are almost similar in both villages. Over $90 \%$ of Mulyorejo Urban village and Karangnongko village respondents are of active age. Most respondents in Mulyorejo Urban village (57\%) and Karangnongko (61.9\%) had non-permanent employment, with wages below $81.1 \%$ and $67.9 \%$, respectively. The respondents in the second study area have basic education.

Respondents' knowledge of methane gas is shown by their ability to identify at least one of the 3 variables, including benefits, impacts, and policies. When the respondent cites one of the variables, they are considered to have methane gas-related knowledge. Table 1 shows that the knowledge of the benefits of methane gas in the Mulyorejo urban village respondents is better than in the Karangnongko. Furthermore, the level of knowledge of methane gas in both regions is low. Knowledge policy is one of the lowest aspects, among other knowledge variables. The percentage of respondents aware of the policy or plan being implemented for the methane gas program is $9.4 \%$ for Mulyorejo Urban village and $6.7 \%$ for Karangnongko. The level of policy knowledge due to program access or implementation is minimal. Only those living around the landfill had knowledge of the policies and programs being implemented.

\subsection{Logistic Regression}

The Logistic Regression Analysis examines the opportunities for factors influencing community participation in CBO methane gas in Mulyorejo urban village and Karangnongko villages. The logistic regression analysis phases comprise several tests, including the Omnibus, the coefficient of determination, the Hosmer and Lemeshow, the model prediction, and the Partial Test.

1. Omnibus Test

The Omnibus or significance test determines whether the independent variables have a real influence on the dependent variable. It a simultaneous test.

Table 2. Comparison of the omnibus test results in Mulyorejo Urban Village and Karangnongko Village

\begin{tabular}{|l|l|c|c|c|}
\hline \multicolumn{2}{|c|}{} & $\begin{array}{c}\text { Chi- } \\
\text { square }\end{array}$ & df & Sig. \\
\hline \multirow{3}{*}{ Mulyorejo } & Step & 156.656 & 14 & .000 \\
\cline { 2 - 5 } & Block & 156.656 & 14 & .000 \\
\cline { 2 - 5 } & Model & 156.656 & 14 & .000 \\
\hline \multirow{3}{*}{ Karangnongko } & Step & 82.678 & 14 & .000 \\
\cline { 2 - 5 } & Block & 82.678 & 14 & .000 \\
\cline { 2 - 5 } & Model & 82.678 & 14 & .000 \\
\hline
\end{tabular}

Based on the table 2, the calculation, the significance value of the omnibus test results in Mulyorejo urban village and Karangnongko villages is 0.000 and less than alpha $(<0.05)$. This means that the independent variables significantly influence the dependent variable simultaneously.

2. Determination coefficient

The determination coefficient is tested to see how much influence the independent variable has on the dependent variable. The value of Negelkerke $R$ Square is interpreted as the value of $\mathrm{R}$ Square in multiple regression (Table 3 ).

Table 3. Comparison of Mulyorejo urban village and Karangnongko village determination coefficient

\begin{tabular}{|l|c|c|c|}
\hline & $\begin{array}{c}\mathbf{- 2} \text { Log } \\
\text { likelihood }\end{array}$ & $\begin{array}{c}\text { Cox \& } \\
\text { Snell R } \\
\text { Square }\end{array}$ & $\begin{array}{c}\text { Nagelkerke } \\
\text { R Square }\end{array}$ \\
\hline Mulyorejo & 64.287 & .474 & .795 \\
\hline Karangnongko & 40.195 & .460 & .767 \\
\hline
\end{tabular}

The value of Cox \& Snell R Square is 0.496 . Similarly, the value of Negelkerke R Square for Mulyorejo urban village and Karangnongko is 0.795 and 0.767 , respectively. This indicates that the extent of the independent variable's effect on the dependent variable in Mulyorejo urban village and Karangnongko villages is $79.5 \%$ and $76.7 \%$, respectively (Table 3). Other independent variables outside the analysis affect $21.5 \%$ to $23.3 \%$ of the remaining dependent variables.

3. Hosmer and Lemeshow Test

Hosmer and Lemeshow or Model Compatibility Test was used to evaluate whether the model used predicts the relationship between independent and dependent variables.

Table 4. Comparison of test results for hosmer and lemeshow in Mulyorejo urban village and Karangnongko village

\begin{tabular}{|l|c|c|c|c|}
\hline & Step & Chi-square & df & Sig. \\
\hline Mulyorejo & 1 & 4.839 & 8 & .775 \\
\hline Karangnongko & 1 & 1.241 & 8 & .996 \\
\hline
\end{tabular}

Table 4. shows the Hosmer and Lemeshow test has a value of 0.775 for Mulyorejo urban village and 0.996 for Karangnongko. The significance value of both is greater than alpha 5\%. Hence, the model used is capable of explaining the data and may interpret the relationship between dependent and independent variables.

4. Predicted Model

In logistic regression analysis, model prediction accuracy is seen. A large percentage of model accuracy is formed. The accuracy of model predictions is achieved by comparing observations with predicted results (Table 5).

Table 5. Comparison of Mulyorejo urban village and

Karangnongko village determination coefficient

Classification Table ${ }^{\mathrm{a}}$ 


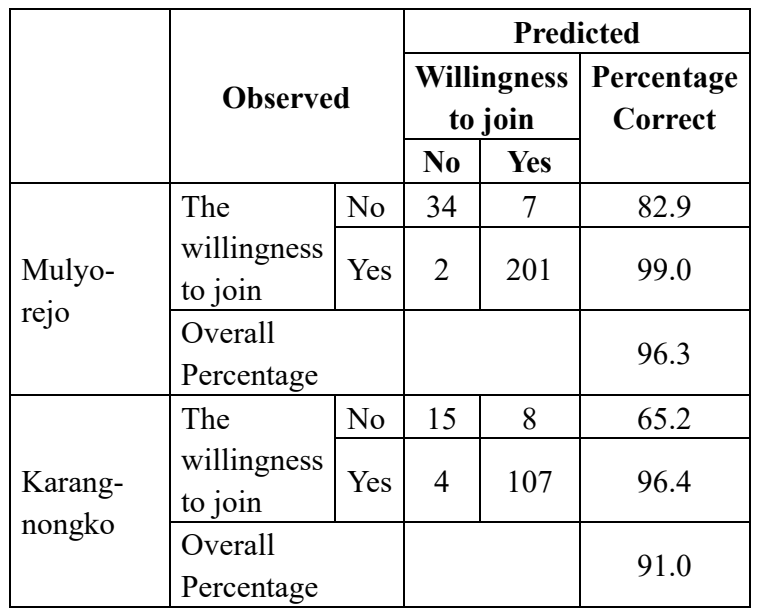

Based on Table 5, the prediction accuracy of the Mulyorejo urban village and Karangnongko village logistic regression model is known through the willingness to join $(\mathrm{Y})$. The degree of classification results predicted by the logistic regression model in the two villages is very good. This is because it predicts with $96.3 \%$ and $91 \%$ accuracy for Mulyorejo urban village and Karangnongko villages, respectively.

5. Partial Test

The significance value indicates the existence or absence of the independent variables' effect on the dependent variable in Mulyorejo Urban Village. When the significance value $<5 \%$, the dependent variable significantly affects each independent variable.

Table 6. Variables in logit model of Mulyorejo Urban Village

\begin{tabular}{|c|c|c|c|c|c|c|c|}
\hline & & $\mathbf{B}$ & S.E. & Wald & df & Sig. & $\operatorname{Exp}(B)$ \\
\hline \multirow{15}{*}{ Step $1^{\mathrm{a}}$} & Network availability (X1) & 1.384 & .865 & 2.562 & 1 & .109 & 3.992 \\
\hline & $\operatorname{Ages}(\mathrm{X} 2)$ & -1.012 & 1.260 & .645 & 1 & .422 & .363 \\
\hline & Occupation (X3) & .531 & .719 & .545 & 1 & .461 & 1.701 \\
\hline & Income (X4) & -3.077 & 1.151 & 7.152 & 1 & $.007 *$ & .046 \\
\hline & Education (X5) & .615 & .784 & .614 & 1 & .433 & 1.849 \\
\hline & Methane gas benefit (X6) & 4.991 & 1.297 & 14.795 & 1 & $.000 *$ & 147.037 \\
\hline & Methane gas impact (X7) & -2.115 & 1.112 & 3.621 & 1 & .057 & .121 \\
\hline & Policy Knowledge (X8) & -.112 & 1.515 & .005 & 1 & .941 & .894 \\
\hline & Awareness (X9) & 2.251 & .869 & 6.716 & 1 & $.010 *$ & 9.500 \\
\hline & Financial (X10) & 2.900 & 1.232 & 5.544 & 1 & $.019 *$ & 18.173 \\
\hline & Social Status (X11) & -1.211 & .954 & 1.609 & 1 & .205 & .298 \\
\hline & Social Participation (X12) & -.971 & .861 & 1.273 & 1 & .259 & .379 \\
\hline & $\begin{array}{l}\text { Invited by family/friends/ } \\
\text { neighbors (X13) }\end{array}$ & 2.807 & .836 & 11.266 & 1 & $.001 *$ & 16.560 \\
\hline & Invited by government (X14) & 5.752 & 1.417 & 16.483 & 1 & $.000 *$ & 314.827 \\
\hline & Constant $\left(\mathrm{B}_{0}\right)$ & -6.507 & 1.946 & 11.179 & 1 & .001 & .001 \\
\hline
\end{tabular}

Depending on the table 6 , the partial test results, 6 independent variables have a significant value $<0.05$, meaning they affect the dependent variable. Significant variables include income (X4) from methane gas (X6), awareness (X9), financial (X10), invitation from friends, neighbors, or family (X13), and the government $(\mathrm{X} 14)$. The odds ratio $(\operatorname{Exp}(\mathrm{B}))$ shows the value of the chances of the respondent joining the $\mathrm{CBO}$ based on the variable. The income variable (X4) has an odds ratio value of $-0,046$. The regression model's negative sign shows that the lower the respondent income, the higher the chance of being willing to join the $\mathrm{CBO}$ methane gas. Therefore, respondents with an income below the RMW have the opportunity to join $\mathrm{CBO}$ methane gas by 0.046 times compared to those with an income above the RMW. The logistic regression equation for Mulyorejo Village based on a significant variable is (Eq. 4):

$$
\begin{gathered}
\operatorname{Ln} \frac{P}{1-P}=-6.507-3,007 \mathrm{X}_{4}+4.991 \mathrm{X}_{6}+2,251 \mathrm{X}_{9} \\
+ \\
2.900 \mathrm{X}_{10}+2.807 \mathrm{X}_{13}+5.752 \mathrm{X}_{14}
\end{gathered}
$$

Whether independent variables influence the dependent variable in Karangnongko Village is seen from each variable's meaning value. When the significance value is $<5 \%$, each independent variable significantly influences the dependent variable. 
Table 7. Variables in logit model of Karangnongko Village

\begin{tabular}{|c|c|c|c|c|c|c|c|}
\hline & & B & S.E. & Wald & df & Sig. & $\operatorname{Exp}(B)$ \\
\hline \multirow{15}{*}{ Step $1^{\mathrm{a}}$} & Network availability (X1) & 2.290 & 1.391 & 2.712 & 1 & .100 & 9.877 \\
\hline & Ages (X2) & -.846 & 2.797 & .091 & 1 & .762 & .429 \\
\hline & Occupation (X3) & -.167 & .894 & .035 & 1 & .852 & .846 \\
\hline & Income (X4) & -1.522 & 1.357 & 1.259 & 1 & .262 & .218 \\
\hline & Education (X5) & .009 & 1.131 & .000 & 1 & .994 & 1.009 \\
\hline & Methane gas benefit (X6) & 4.088 & 1.932 & 4.476 & 1 & $.034 *$ & 59.612 \\
\hline & Methane gas impact (X7) & -1.957 & 1.216 & 2.588 & 1 & .108 & .141 \\
\hline & Policy Knowledge (X8) & -1.258 & 1.191 & 1.116 & 1 & .291 & .284 \\
\hline & Awareness (X9) & -1.515 & 1.197 & 1.601 & 1 & .206 & .220 \\
\hline & Financial (X10) & 2.724 & 1.245 & 4.790 & 1 & $.029 *$ & 15.244 \\
\hline & Social Status (X11) & .358 & 1.162 & .095 & 1 & .758 & 1.430 \\
\hline & Social Participation (X12) & 3.340 & 1.566 & 4.547 & 1 & $.033 *$ & 28.218 \\
\hline & $\begin{array}{l}\text { Invited by family/friends/ } \\
\text { neighbors (X13) }\end{array}$ & 3.341 & 1.609 & 4.314 & 1 & $.038 *$ & 28.246 \\
\hline & Invited by government (X14) & 3.325 & 1.648 & 4.069 & 1 & $.044 *$ & 27.788 \\
\hline & Constant $\left(\mathrm{B}_{0}\right)$ & -5.941 & 3.627 & 2.683 & 1 & .101 & .003 \\
\hline
\end{tabular}

Table 7 shows the significant value of each independent variable of the study. The independent variable with a meaning value $<0.05$ was considered important and affected the dependent variable. Significant variables include methane gas (X6), financial (X10), social engagement (X12), friends, neighbors, or family invitation (X13), and government invitation (X14). The odds ratio $(\operatorname{Exp}(B))$ indicates the numerical value of the respondent's chance to enter the CBO. For instance, the methane gas benefit variable (X6) has an odds ratio value of 59.612. This means that respondents with the knowledge of the benefits of methane gas have a 59.612-fold opportunity to join the CBO compared to those that do no know. The Karangnongko Village's logistic regression equation is as follows (Eq. 5):

$$
\begin{aligned}
& \operatorname{Ln} \frac{P}{1-P}=-5.941+4.088 \mathrm{X}_{6}+2.724 \mathrm{X}_{10}+ \\
& 3.340 \mathrm{X}_{12}+3.341 \mathrm{X}_{13}+3.325 \mathrm{X}_{14}
\end{aligned}
$$

6. Probability Analysis

Logistic regression is a dependent variable. It is a linear combination of independent variables. The value of the dependent variable is then transformed into the probability of the logit function. Also, logistic regression produces an odds ratio related to the value of each independent variable. The following is an equal opportunity to join $\mathrm{CBO}$ methane gas (Eq. 6) and (Eq. 7).

Pwillingness to join the village of Mulyorejo

$=\frac{e^{(-6,507-3,007 \mathrm{X} 4+4,991 \mathrm{X} 6+2,251 \mathrm{X} 9+2,900 \mathrm{X} 10+2,807 \mathrm{X} 13+5,752 \mathrm{X} 14)}}{1+e^{(-6,507-3,007 \mathrm{X} 4+4,991 \mathrm{X} 6+2,251 \mathrm{X} 9+2,900 \mathrm{X} 10+2,807 \mathrm{X} 13+5,752 \mathrm{X} 14)}}$

PWillingness to join the village of Karangnongko

$=\frac{e^{(-5,941+4,088 \times 6+2,724 \times 10+3,340 \times 12+3,341 \times 13+3,325 \times 14)}}{1+e^{(-5,941+4,088 \times 6+2,724 \times 10+3,340 \times 12+3,341 \times 13+3,325 \times 14)}}$

The probability of the willingness to join the CBO methane gas is analyzed after developing the logistic regression model. The model is used to determine the scenario of opportunities to join the CBO community.

\begin{tabular}{|c|c|c|c|c|}
\hline \multirow{2}{*}{ No. } & \multicolumn{2}{|l|}{ Mulyorejo urban village } & \multicolumn{2}{|l|}{ Karangnongko village } \\
\hline & Scenarios & Probability & Scenarios & Probability \\
\hline 1. & $\begin{array}{ll}\text { - } & \text { Income }(0) \\
\text { - } & \text { Methane gas benefit }(0) \\
\text { - } & \text { Financial }(0) \\
\text { - } & \text { Awareness }(0) \\
\text { - } & \text { Invited by family/friends/ neighbors }(0) \\
\text { - } & \text { Invited by government }(0)\end{array}$ & $0.00 \%$ & $\begin{array}{ll}\text { - } & \text { Income }(0) \mathrm{s} \\
\text { - } & \text { Methane gas benefit }(0) \\
\text { - } & \text { Financial }(0) \\
\text { - } & \text { Awareness }(0) \\
\text { - } & \text { Invited by family/friends/ neighbors } \\
& (0)\end{array}$ & $000 \%$ \\
\hline
\end{tabular}

Table 8. Comparison of CSO methane gas scenarios Mulyorejo urban village and Karangnongko villages 


\begin{tabular}{|c|c|c|c|c|}
\hline \multirow{2}{*}{ No. } & \multicolumn{2}{|l|}{ Mulyorejo urban village } & \multicolumn{2}{|l|}{ Karangnongko village } \\
\hline & Scenarios & Probability & Scenarios & Probability \\
\hline & & & - $\quad$ Invited by government (0) & \\
\hline 2. & $\begin{array}{ll}\text { - } & \text { Income }(1) \\
\text { - } & \text { Methane gas benefit }(0) \\
\text { - } & \text { Financial }(0) \\
\text { - } & \text { Awareness }(0) \\
\text { - } & \text { Invited by family/friends/ neighbors }(0) \\
\text { - } & \text { Invited by government }(0)\end{array}$ & $0.007 \%$ & $\begin{array}{ll}\text { - } & \text { Methane gas benefit }(0) \\
\text { - } & \text { Financial }(0) \\
\text { - } & \text { Social Participation }(0) \\
\text { - } & \text { Invited by family/friends/ neighbors } \\
& (0) \\
\text { - } & \text { Invited by government }(1)\end{array}$ & $6.81 \%$ \\
\hline 3. & $\begin{array}{ll}\text { - } & \text { Income }(0) \\
\text { - } & \text { Methane gas benefit (1) } \\
\text { - } & \text { Financial }(0) \\
\text { - } & \text { Awareness }(0) \\
\text { - } & \text { Invited by family/friends/ neighbors }(0) \\
\text { - } & \text { Invited by government }(0)\end{array}$ & $1.074 \%$ & $\begin{array}{ll}\text { - } & \text { Methane gas benefit }(1) \\
\text { - } & \text { Financial }(0) \\
\text { - } & \text { Social Participation }(0) \\
\text { - } & \text { Invited by family/friends/ neighbors } \\
& (0) \\
\text { - } & \text { Invited by government }(0)\end{array}$ & $13.55 \%$ \\
\hline 4. & $\begin{array}{ll}\text { - } & \text { Income (1) } \\
\text { - } & \text { Methane gas benefit (1) } \\
\text { - } & \text { Financial (1) } \\
\text { - } & \text { Awareness }(0) \\
\text { - } & \text { Invited by family/friends/ neighbors }(0) \\
\text { - } & \text { Invited by government }(0)\end{array}$ & $9.346 \%$ & $\begin{array}{ll}\text { - } & \text { Methane gas benefit }(0) \\
\text { - } & \text { Financial }(0) \\
\text { - } & \text { Social Participation }(0) \\
\text { - } & \text { Invited by family/friends/ neighbors } \\
& (1) \\
\text { - } & \text { Invited by government (1) }\end{array}$ & $67.37 \%$ \\
\hline 5. & $\begin{array}{ll}\text { - } & \text { Income }(0) \\
\text { - } & \text { Methane gas benefit }(0) \\
\text { - } & \text { Financial }(0) \\
\text { - } & \text { Awareness }(0) \\
\text { - } & \text { Invited by family/friends/ neighbors }(0) \\
\text { - } & \text { Invited by government }(1)\end{array}$ & $31.973 \%$ & $\begin{array}{ll}\text { - } & \text { Methane gas benefit (1) } \\
\text { - } & \text { Financial ( } 1) \\
\text { - } & \text { Social Participation (0) } \\
\text { - } & \text { Invited by family/friends/ neighbors } \\
& (0) \\
\text { - } & \text { Invited by government }(0)\end{array}$ & $70.83 \%$ \\
\hline 6. & $\begin{array}{ll}\text { - } & \text { Income (1) } \\
\text { - } & \text { Methane gas benefit (1) } \\
\text { - } & \text { Financial (1) } \\
\text { - } & \text { Awareness }(1) \\
\text { - } & \text { Invited by family/friends/ neighbors }(0) \\
\text { - } & \text { Invited by government }(0)\end{array}$ & $65.204 \%$ & $\begin{array}{ll}\text { - } & \text { Methane gas benefit }(0) \\
\text { - } & \text { Financial }(0) \\
\text { - } & \text { Social Participation (1) } \\
\text { - } & \text { Invited by family/friends/ neighbors } \\
& (1) \\
\text { - } & \text { Invited by government (1) }\end{array}$ & $98.31 \%$ \\
\hline 7. & $\begin{array}{ll}\text { - } & \text { Income }(0) \\
\text { - } & \text { Methane gas benefit }(0) \\
\text { - } & \text { Financial }(0) \\
\text { - } & \text { Awareness }(0) \\
\text { - } & \text { Invited by family/friends/ neighbors (1) } \\
\text { - } & \text { Invited by government (1) }\end{array}$ & $88.615 \%$ & $\begin{array}{ll}\text { - } & \text { Methane gas benefit (1) } \\
\text { - } & \text { Financial (1) } \\
\text { - } & \text { Social Participation (1) } \\
\text { - } & \text { Invited by family/friends/ neighbors } \\
& (0) \\
\text { - } & \text { Invited by government }(0)\end{array}$ & $98.56 \%$ \\
\hline 8. & $\begin{array}{ll}\text { - } & \text { Income (1) } \\
\text { - } & \text { Methane gas benefit (1) } \\
\text { - } & \text { Financial (1) } \\
\text { - } & \text { Awareness (1) } \\
\text { - } & \text { Invited by family/friends/ neighbors (1) } \\
\text { - } & \text { Invited by government (0) }\end{array}$ & $96.878 \%$ & $\begin{array}{ll}\text { - } & \text { Methane gas benefit (1) } \\
\text { - } & \text { Financial (1) } \\
\text { - } & \text { Social Participation (1) } \\
\text { - } & \text { Invited by family/friends/ neighbors } \\
& (1) \\
\text { - } & \text { Invited by government (0) }\end{array}$ & $99.88 \%$ \\
\hline 9. & $\begin{array}{ll}\text { - } & \text { Income }(0) \\
\text { - } & \text { Methane gas benefit }(0) \\
\text { - } & \text { Financial }(0) \\
\text { - } & \text { Awareness (1) } \\
\text { - } & \text { Invited by family/friends/ neighbors (1) } \\
\text { - } & \text { Invited by government (1) }\end{array}$ & $99.298 \%$ & $\begin{array}{ll}\text { - } & \text { Methane gas benefit (0) } \\
\text { - } & \text { Financial (1) } \\
\text { - } & \text { Social Participation (1) } \\
\text { - } & \text { Invited by family/friends/ neighbors } \\
& (1) \\
\text { - } & \text { Invited by government (1) }\end{array}$ & $99.88 \%$ \\
\hline 10. & $\begin{array}{ll}- & \text { Income }(0) \\
\text { - } & \text { Methane gas benefit }(0) \\
\end{array}$ & $99.926 \%$ & $\begin{array}{ll}- & \text { Methane gas benefit (1) } \\
\text { - } & \text { Financial (1) } \\
\end{array}$ & $99.99 \%$ \\
\hline
\end{tabular}




\begin{tabular}{|c|c|c|c|c|}
\hline \multirow{2}{*}{ No. } & \multicolumn{2}{|l|}{ Mulyorejo urban village } & \multicolumn{2}{|l|}{ Karangnongko village } \\
\hline & Scenarios & Probability & Scenarios & Probability \\
\hline & $\begin{array}{ll}\text { - } & \text { Financial (1) } \\
\text { - } & \text { Awareness (1) } \\
\text { - } & \text { Invited by family/friends/ neighbors (1) } \\
\text { - } & \text { Invited by government (1) }\end{array}$ & & $\begin{array}{ll}\text { - } & \text { Social Participation (1) } \\
\text { - } & \text { Invited by family/friends/ neighbors } \\
\text { (1) } & \text { Invited by government (1) }\end{array}$ & \\
\hline 11. & $\begin{array}{ll}- & \text { Income (1) } \\
\text { - } & \text { Methane gas benefit (1) } \\
\text { - } & \text { Financial (1) } \\
\text { - } & \text { Awareness (1) } \\
\text { - } & \text { Invited by family/friends/ neighbors (1) } \\
\text { - } & \text { Invited by government (1) }\end{array}$ & $99.990 \%$ & & \\
\hline 12. & $\begin{array}{ll}\text { - } & \text { Income }(0) \\
\text { - } & \text { Methane gas benefit (1) } \\
\text { - } & \text { Financial (1) } \\
\text { - } & \text { Awareness (1) } \\
\text { - } & \text { Invited by family/friends/ neighbors (1) } \\
\text { - } & \text { Invited by government (1) }\end{array}$ & $99.999 \%$ & & \\
\hline
\end{tabular}

Based on Table 8, the tenth and twelfth scenarios are the most applied in Karangnongko and Mulyorejo villages, respectively. Both scenarios have a $99 \%$ chance of the community joining the CBO. Also, the determination of the most suitable scenario is seen from the facts in the field. The survey results in Mulyorejo's respondents show that the knowledge on the benefits (including financial) of methane gas, awareness, requests from the closest people, and the government have a high degree of influence. The income aspect is low because $81.1 \%$ of respondents earn below the RMW. Therefore, the tenth scenario is the most suitable for application in Mulyorejo Village because, though the respondent's income is low, it has an enormous opportunity to join. In Karangnongko Village, the opportunity to join was very high. This is because respondents reacted positively to the invitation to join. Although the respondents have a low level of awareness $(68.7 \%$ lack the awareness to join) and knowledge of methane gas benefit ( $40.3 \%$ do not know the benefits of methane gas), the invitation variable of the closest people significantly increases the value of the opportunity to join the community.

In Mulyorejo and Karangnongko villages, the invitation element of relatives, friends, or neighbors plays a significant role in raising the opportunity to join both study areas. The invitation factor for relatives, friends, or neighbors in Karangnongko and Mulyorejo Urban village respondents increased the chance of joining by $60.56 \%$ and $56.64 \%$, respectively. This shows that family, friends, and neighbors significantly shape respondents' willingness to join CBO's. This influence on social capital typology is seen in both regions. Previous research found that the typology in Mulyorejo Urban village and Karangnongko villages was bonding social capital ${ }^{1)}$. This typology appears to be exclusive because it is focused on the bonds that are the glue in a society. Communities in this group generally have homogeneous norms, values, interactions, and knowledge. Hence, the community groups are often called sacred societies ${ }^{36)}$ that prioritize norms and maintain the closed nature. Furthermore, they maintain their community structure and low openness. Regular contact behaviors aim to prioritize norms, favoring group members. While this community has strong exclusivity, building good social capital is not powerful enough. Therefore, the invitation factor for relatives, friends, or neighbors in Karangnongko and Mulyorejo Urban villages greatly influences respondents to join $\mathrm{CBO}$. This is because social features have close family ties, and the community is homogeneous.

In addition to the invitation from relatives, friends, or neighbors, other factors play a role in increasing the opportunity to enter the study field. These include the awareness and social participation factors in Mulyorejo Urban village and Karangnongko villages, respectively. Mulyorejo Urban Village's awareness factor increases the chance to enter up to $55.85 \%$. In Karangnongko Village, the social engagement factor increases the opportunity to $22.98 \%$. Mulyorejo Urban Village respondents strongly understand joining the $\mathrm{CBO}$, as the local population knows the benefits of methane gas. The world generally knows about the greenhouse gas system in the natural gas sector and understands the effects when methane gas is not used properly. The social participation factor increases the ability to join. This is because it relates to the social characteristics of the Karangnongko Village population. Based on social capital assessment ${ }^{1)}$, Karangnongko Village has a high degree of institutional involvement and participation. 
This is evidenced by the $81 \%$ of Karangnongko Village respondents participating in 2 or 3 institutions, indicating a strong understanding of engaging in an organization.

Previous studies indicate a connection between social capital and participation. Social capital underlies the creation of organizational networks. It is a vital resource for the success of organizational coordination. Social capital affects group involvement in political governance and growth ${ }^{37}$. To increase cultural participation, social capital must be improved. Community involvement is affected by socio-cultural, economic, and educational rates. Also, community engagement in infrastructural growth is seen from its contribution ${ }^{38)}$. Group involvement is often affected by long-stay and contact with the local environment. Hence, the longer a person stays in an area, the community's sense of belonging increases the involvement in neighborhood activities ${ }^{39)}$. A variety of studies concentrate on social capital's influence on different forms of engagement, including political, social, and group participation. This means that individual-owned social capital is seen as the ability or capacity to improve the organization's relationships and networks where they belong. This is consistent with previous studies that social capital underlies organizational networking and affects engagement ${ }^{37)}$. The higher the social capital, the greater the civic and social engagement.

Regarding this, the relation between social capital and the potential for membership is seen from the hypothesis that network size is determined by the number of participants in the community ${ }^{9)}$. This study invites the community to participate in the CBO methane gas. This is aimed at increasing the social network in the methane gas community. A greater network size increases access to social capital services. Consequently, methane gas is projected to increase social capital as more people join CBO. It is shown by the presence of social participation variables in the Karangnongko Village scenario model. Social capital shapes engagement in society. 37) Hence, effective social participation improves community involvement. Also, it may influence the ability to collect social capital.

\section{Conclusion}

Previous studies have shown that individual behavior directly or indirectly impacts the environment ${ }^{20)}$. In this study, individual behavior is associated with the willingness to take advantage of methane gas emissions through joining CBOs. This behavior is influenced by knowledge, psychological factors, and the social demographic conditions of each individual.

Environmental knowledge significantly shapes behavior that cares about the environment ${ }^{20)}$. Knowledge raises awareness and action to overcome environmental problems. Psychological factors are summarized in the motivation to join, such as awareness, social status, invitation, and the benefits obtained.

The socio-demographic conditions of each individual influence knowledge and psychological factors. These conditions include income, education level, and occupation. They influence the decision to join a CBO. Low-income communities (LIC) are more careful to see whether joining a CBO is beneficial or not. The results showed that the financial variable on LIC's has a high percentage $(68 \%$ for Mulyorejo and $73 \%$ for Karangnongko) to influence respondents to join the CBO.

Understanding the factors influencing individual behavior to join CBOs reduces air pollution and greater environmental damage. In this study, the factors were the willingness and awareness of the importance of reducing methane gas released into the air.

This study determines public reactions and responses regarding the presence of methane gas and its future development plans. The Government of Malang City has a program to develop methane gas networks in the villages by the end of 2020 . Therefore, this study determines the opportunities for the public interest in using methane gas through CBOs. The community opportunity to join was assessed from individual behavioral factors. The factors influencing individuals in handling waste were adopted from previous research ${ }^{29)}$. These opportunities and their magnitudes are realized in the form of scenarios. The results for the respondents of Mulyorejo urban village show that the opportunity to join is up to $99 \%$ in the twelfth scenario. This scenario requires the respondent to know the benefits of methane gas to the community, have the awareness to join CBOs, and an invitation from family, friends, neighbors, and the government to reach $99 \%$. The financial factor plays an essential role for the respondents of Mulyorejo Urban village to join CBO. As many as $81.1 \%$ of Mulyorejo Village respondents had an income below the RMW, and $68.8 \%$ of them agreed that the financial factor was the reason for joining the $\mathrm{CBO}$. One of the advantages of joining a CBO is getting methane gas as a substitute for LPG, reducing household expenses. This scenario references the Malang City Government to attract the community's attention to utilizing methane gas. Therefore, socialization and education are needed in advance for people to understand the importance and benefits of using methane gas.

The same goes for Karangnongko Village, which plans to develop a methane gas network on a broader scale. The distribution of methane gas currently only meets the needs of the people of Dusun Paras. In the future, the Village Government hopes that all residents of Karangnongko felt the benefits of methane gas. The tenth scenario is the most suitable for application in Karangnongko Village. The opportunity to join reaches $99 \%$ when the community knows the benefits of methane gas, gets financial benefits, increases social participation, and there is an invitation 
from family, friends, neighbors, and the government. Respondents that knew the benefits of methane gas were $59.7 \%$. Moreover, $73.1 \%$ of respondents agreed to join for financial reasons. When people know the benefits of methane gas, they save money on buying LPG gas. The number of respondents that knew the benefits of methane gas in Karangnongko Village was lower than in Mulyorejo Urban village. Therefore, to realize the network extension program, the Village Government should enlightenthe Karangnongko Village community regarding itsbenefits. In rural communities, leaders, neighbors, and relatives significantly influence decision-making. Therefore, approaching community leaders is the key to a high interest in joining CBOs.

\section{Acknowledgments}

We would thanks to Dean of Engineering Faculty, Brawijaya University. Anonymous Reviewers, the Editor in Chief and Executive Editor. The author is solely responsible for the content and the views expressed.

\section{References}

1) A.N. Hakim, G. Prayitno, and C. Meidiana, "Comparative study of social capital in self-help group ( study in mulyorejo and karangnongko village )," Int. J. Innov. Sci. Res. Technol., 4 (12) 6270 (2019).

2) M. Ayadi, S. Ahou, S. Awad, M. Abderrabba, and Y. Andres, "Production of biogas from olive pomace," Evergreen, $7 \quad$ (2) 228-233 (2020). doi: $10.5109 / 4055224$.

3) T.M. Mostafa, and D.S. Sarhan, "Economic feasibility study of e-waste recycling facility in egypt," Evergreen, 5 (2) 26-35 (2018). doi:10.5109/1936214.

4) A.K. Nayak, "Developing social capital through selfhelp groups," 7 (1) 18-24 (2015).

5) M. Fafchamps, and E. La Ferrara, "Self-help groups and mutual assistance: evidence from urban kenya," Econ. Dev. Cult. Change, 60 (4) 707-733 (2012). doi:10.1086/665600.

6) G. Prayitno, N. Sari, and I.K. Putri, "Social capital in poverty alleviation through pro-poor tourism concept in slum area (case study: kelurahan jodipan, malang city)," Int. J. GEOMATE, (2019). doi:10.21660/2019.55.37152.

7) S.C. Bharamappanavara, and M. Jose, "Group dynamics and collective performance of self-help groups under different microcredit delivery models in karnataka," Agric. Econ. Res. Rev., 28 (1) 127 (2015). doi:10.5958/0974-0279.2015.00010.5.

8) Z.F. Zahara, "Economic assessment of the sugarcanebased bio-refinery in indonesia," Evergreen, 5 (2) 6777 (2018). doi:10.5109/1936219.

9) M.S. Barliana, and D. Cahyani, "Arsitektur, Urbanitas, dan Pendidikan Budaya Berkota," Departemen Pendidikan Arsitektur, UPI, Bandung, 2014.
10) S. Wasserman, and K. Faust, "Social Network Analysis: Methods and Applications," First Edit, Cambridge University Press, USA, 1994. doi: $10.2307 / 3322457$.

11) R. Syahli, and B. Sekarningrum, "Pengelolaan sampah berbasis modal sosial masyarakat.," Sosiogobal J. Pemikir. Dan Penelit. Sosiol., 1 (2) 143-151 (2017). doi:10.24198/jsg.v1i2.13309.

12) J. DeFilippis, "The myth of social capital in community development," Hous. Policy Debate, 12 (4) 781-806 (2001). doi:10.1080/10511482.2001.9521429.

13) F.O. Walumbwa, and A.L. Christensen, "The importance of social capital in the workplace and how individuals and organizations can support its development," Fulfilling Work. - Organ. Role Achiev. Individ. Organ. Heal., (January 2013) 105-117 (2013).

14) G. Prayitno, and M. Syaifurridzal, "Social Capital and Public Participation on Planning in Coastal Area Development," in: IOP Conf. Ser. Earth Environ. Sci., 2017. doi:10.1088/1755-1315/79/1/012019.

15) D. Johar, "Peran modal sosial dalam meningkatkan peran lembaga keuangan mikro dalam pembangunan pertanian di sumatera barat," J. Ekon. Univ. Borobudur, 16 (October 2014) 285-288 (2014).

16) B. Brown, D.D. Perkins, and G. Brown, "Place attachment in a revitalizing neighborhood: individual and block levels of analysis," J. Environ. Psychol., 24 (1) 259-271 (2004). doi:doi.org/10.1016/S02724944(02)00117-2.

17) S. Geber, H. Scherer, and D. Hefner, "Social capital in media societies: the impact of media use and media structures on social capital," Int. J. Gaz., 78 (6) 493513

(2016). doi:https://doi.org/10.1177/1748048516640211.

18) H. Gima, and T. Yoshitake, "A comparative study of energy security in okinawa prefecture and the state of hawaii," Evergreen, 3 (2) 36-44 (2016). doi:10.5109/1800870.

19) M. Nazir, "Metode Penelitian," Ghalia Indonesia, Bogor, 2005.

20) S. Barr, "Factors influencing environmental attitudes and behaviors: a u.k. case study of household waste management," Environ. Behav., 39 (4) 435-473 (2007). doi:doi.org/10.1177/0013916505283421.

21) J. Coleman, "Social capital in the creation of human capital author," Am. J. Sociol., 94 (Supplement) S95S120 (1988). doi:10.1037/0012-1649.22.6.723.

22) I.I. Maharani, H. Hardinsyah, and B. Sumantri, "Aplikasi regresi logistik dalam analisis faktor risiko anemia gizi pada mahasiswa baru ipb," J. Gizi Dan $\begin{array}{lllll}\text { Pangan, } & 2 & \text { (2) } & 36 & \text { (2007). }\end{array}$ doi:10.25182/jgp.2007.2.2.36-43.

23) S. Sperandei, "Understanding logistic regression analysis.," Biochem. Medica, 24 (1) 12-18 (2014). doi:doi.org/10.11613/BM.2014.003. 
24) H.A. Park, "An introduction to logistic regression: from basic concepts to interpretation with particular attention to nursing domain," J. Korean Acad. Nurs., $43 \quad$ (2) $154-164 \quad$ (2013). doi:10.4040/jkan.2013.43.2.154.

25) E. Hayati, "Analisis regresi logistik untuk mengetahui faktor-faktor yang mempengaruhi frekuensi kedatangan pelanggan di pusat perbelanjaan 'x,'” J. Ekon. Bisnis, 12 (3) 1-18 (2014).

26) S. Yamin, L. Rachmah, and H. Kurniawan, "Regresi dan Korelasi dalam Genggaman Anda: Aplikasi dengan Software SPSS, Eviews, Minitab, dan Statgraphics," Salemba Empat, Jakarta, 2011.

27) R. Hendayana, "Penerapan metode regresi logistik dalam menganalisis adopsi teknologi pertanian," Inform. Pertan., $22 \quad$ (1) 1 (2015). doi:10.21082/ip.v22n1.2013.p1-9.

28) H. Latan, "Aplikasi Analisis Data Statistik untuk Ilmu Sosial Sains dengan STATA," ALFABETA, Bandung, 2014.

29) BPS, "Kabupaten Malang Dalam Angka 2019," Malang, 2019.

30) Sugiyono, "Metode Penelitian Bisnis: Pendekatan Kuantitatif, Kualitatif, Kombinasi, dan R\&D," 3rd ed., ALFABETA, Bandung, 2017.

31) S.K. Deb, N. Deb, and S. Roy, "Investigation of factors influencing the choice of smartphone banking in bangladesh," Evergreen, 6 (3) 230-239 (2019). doi: $10.5109 / 2349299$.

32) Koderi, Suyadi, A. Said, and A.W. Muhaimin, "Knowledge, action, perception and attitude of management of talangagung landfill toward edutourism program: a community perspective," $J$. Indones. Tour. Dev. Stud., 6 (1) 41-48 (2018). doi:10.21776/ub.jitode.2018.006.01.06.

33) The Minister of Manpower and Transmigration, "REGARDING PROVISIONS FOR THE IMPLEMENTATION OF THE CERTAIN TIME WORK AGREEMENT," Indonesia, 2004.

34) The Republic of Indonesia, "NATIONAL EDUCATION SYSTEM," 2003.

35) T. Sato, "How is a sustainable society established? a case study of cities in japan and germany," Evergreen, 3 (2) 25-35 (2016). doi:10.5109/1800869.

36) I.I. Marhalim, "Strategi Penguatan Modal Sosial Kelompok Swadaya Masyarakat (KSM) Pada Program Community Development PT. Newmont Nusa Tenggara," IPB University, 2015.

37) M.Z. Khalili, M.R. Khalili, and A.B. Inalo, "The effect of social capital on social participation among citizens in behshahr, iran," 2 (3) 3002-3009 (2013).

38) I.G. Engka, C.R. Ngangi, and C.B. Pakasi, "Partisipasi masyarakat dalam kegiatan pembangunan jalan pertanian di aertrang kelurahan malalayang i timur manado," AGRISOSIOEKONOMI, $11 \quad$ (3) 15-24 (2015). doi:10.35791/agrsosek.11.3.2015.9569.
39) H. Suroso, A. Hakim, and I. Noor, "Faktor-faktor yang mempengaruhi partisipasi masyarakat dalam perencanaan pembangunan di desa banjaran kecamatan driyorejo kabupaten gresik," Wacana J. Soc. Humanit. Stud., 17 (1) 7-15 (2014). https://wacana.ub.ac.id/index.php/wacana/article/vie w/290. 